\title{
Implementation Of Cambridge Worry Scale As A Psychological Assesment In Antenatal Care Routine
} Ayu Nurdiyan, Yulizawati, Lusiana Elsinta B, Detty Iryani, Aldina Ayunda Insani

Prodi S1 Kebidanan FK-UNAND, Jln. Niaga No.56 Kota Padang, 25127, Indonesia

\section{INFORMASI ARTIKEL:}

\section{Riwayat Artikel :}

Tanggal diterima : Mei 2016

Tanggal direvisi : Oktober 2016

Tanggal Publikasi : Desember 2016

\section{ABSTRAK}

Kehamilan adalah masa transisi dalam kehidupan perempuan. Pada kehamilan, ada perubahan fisiologis dan psikologis. Tingkat kegelisahan yang meningkat selama kehamilan dapat mempengaruhi aliran darah ibu dan berkontribusi pada hasil obstetrik, janin dan neonatal yang buruk. Penggunaan asesmen psikologis antenatal dapat meningkatkan kesadaran bidan terhadap risiko psikososial dan juga memperbaiki hasil kesehatan mental perinatal. Penilaian psikologis biasa yang digunakan di Indonesia untuk mendapatkan perasaan dan status emosional wanita terlalu sederhana dan tidak cukup untuk menggambarkan perasaan wanita. Banyak kuesioner telah dikembangkan dan diuji di banyak negara namun tidak satupun yang pernah diuji di Indonesia.

Salah satu penilaian psikologis antenatal adalah skala kekhawatiran Cambridge. Berdasarkan latar belakang itu saya memiliki minat untuk belajar tentang "Penerapan skala kekhawatiran Cambridge sebagai penilaian psikologis dalam rutinitas perawatan antenatal". Penelitian ini akan meningkatkan kesadaran bidan dalam menggunakan penilaian psikologis antenatal dalam perawatan antenatal rutin, sehingga faktor risiko psikologis dan psikososial selama kehamilan akan dinilai dengan cepat dan wanita dengan faktor risiko psikososial akan memiliki perawatan yang sesuai. Dengan deteksi faktor risiko psikologis, kita dapat mencegah hasil kelahiran yang buruk dan perkembangan bayi dan anak yang buruk. Dengan menggunakan skala kekhawatiran Cambridge dalam penilaian antenatal, deteksi faktor risiko psikologis akan sesuai dan cukup memadai untuk menggambarkan status emosional dan psikologis Ibu..

Kata kunci: Cambridge Worry Scale; Pengkajian Psikologis; Antenatal care

\begin{abstract}
Pregnancy is a transition period in women's life. In pregnancy, there are physiologic and psychological changes. Enhanced levels of anxiety during pregnancy may affect maternal blood flow and contribute to adverse obstetric, fetal and neonatal outcomes. The use of antenatal psychological assessment may increase the midwives awareness of psychosocial risk and also improved perinatal mental health outcomes. Usual psychological assessment that used in Indonesia for obtaining women's feeling and emotional status is too simple and not enough to describe women's feeling. Many questionnaires have been developed and tested in many countries but none of them have been tested in Indonesia.

One of antenatal psychological assessment is Cambridge worries scale. Based on that background I have an interest to study about "Implementation of Cambridge worries scale as a psychological assessment in antenatal care routine". This project will increase midwives awareness in using antenatal psychological assessment in routine antenatal care, so that psychological and psychosocial risk factor during pregnancy will be assess quickly and women with psychosocial risk factor will have suitable care. By detection of psychological risk factor, we can prevent any adverse birth outcome and poor infant and child development. By using Cambridge worries scale in antenatal assessment, the psychological risk factor detection will be appropriate and well enough to describe emotional and psychological status of women.

Key word: Cambridge Worry Scale; Psychological Assessment; Antenatal Care
\end{abstract}




\section{PENDAHULUAN}

Kehamilan adalah masa transisi dalam kehidupan perempuan. Pada kehamilan, ada perubahan fisiologis dan psikologis. Tingkat kegelisahan yang meningkat selama kehamilan dapat mempengaruhi aliran darah ibu dan berkontribusi pada hasil obstetrik, janin dan neonatal yang buruk. Ada banyak alasan mengapa wanita jatuh cemas dan khawatir dengan kehamilan mereka. Namun, kekhawatiran terkait kehamilan dapat menyebabkan kecemasan kehamilan tingkat tinggi yang muncul sebagai salah satu prediktor psikologis paling kuat dari hasil kelahiran yang buruk dan juga terlibat dalam perkembangan anak dan bayi yang kurang.

Keluarga adalah unit paling dasar dalam masyarakat yang telah bertahan selama berabadabad karena keluarga menyediakan kebutuhan vital manusia. Kehidupan keluarga mempunyai banyak gaya berbeda dan cara berbeda dalam berhubungan dengan masyarakat. Apapun bentuknya, keluarga pasti akan tetap ada selama manusia terus mendiami planet ini. Lazimnya, melahirkan berperan sangat penting dalam keluarga, dan keluarga juga memberikan pengaruh utama pada setiap persepsi yang dimiliki oleh generasi baru mengenai kehamilan, melahirkan dan pengasuhan anak.

Setiap anggota keluarga memikul peran yang sebagian didikte oleh harapan budaya. Persepsi tiap anggota keluarga mengenai peran ini berbeda-beda berdasarkan cara hidup bermasyarakat dan jenis interaksi yang telah ia lakukan dengan orang lain. Masyarakat berkembang dan berubah, begitu juga berbagai harapan peran. Setiap generasi turun temurun dapat memiliki harapan berbeda karena mereka beradaptasi dengan perubahan waktu dan kebutuhan, meskipun selalu ada pembatasanpembatasan sosial.

Begitu juga dengan melahirkan. Kehamilan dan kelahiran adalah kejadian penting pada sebagian besar kebudayaan. Bagaimanapun, sikap terhadap proses ini sangat beragam antarbudaya yang berbeda dan bahkan dalam sebuah masyarakat. Pada beberapa budaya, kelahiran adalah sebuah peristiwa sosial, dengan kehadiran seluruh teman dan keluarga secara terbuka. Demikian pula, kehamilan dapat dilihat sebagai suatu fase persiapan normal yang menakjubkan menuju perubahan status yang diharapkan yang menandakan pencapaian baru.

Kehamilan adalah masa hidup seorang wanita yang penuh dengan antisipasi yang menyenangkan pada bayi, yang mungkin dipengaruhi oleh beberapa tekanan psikologis. Penelitian tentang keadaan psikologis di Indonesia.

Kehamilan menunjukkan bahwa setiap trimester kehamilan termasuk kemungkinan stresor yang dapat memicu beberapa kekhawatiran pada wanita hamil. Beberapa penelitian menemukan tingkat kekhawatiran yang meningkat pada trimester pertama dan ketiga kehamilan sementara yang lain menunjukkan bahwa setiap aspek kekhawatiran wanita hamil dapat berfluktuasi sepanjang masa kehamilan. Beberapa penelitian menunjukkan bahwa kekhawatiran tentang kemungkinan kehilangan bayi, kesehatan bayi, dan persalinan merupakan penyebab kekhawatiran yang umum terjadi pada wanita hamil. Selain kekhawatiran semacam ini, ada sumber kekhawatiran lain dalam kehidupan sehari-hari wanita (mis., Khawatir tentang uang, pekerjaan, perumahan, kesehatan, dan hubungan perkawinan mereka). Kebanyakan wanita mengalami beberapa kekhawatiran ringan selama kehamilan; Namun, beberapa wanita mungkin mengalami kekhawatiran patologis, yang didefinisikan sebagai pikiran negatif yang tidak terkendali dan kekhawatiran yang berlebihan tentang kejadian masa depan dalam kehamilan yang dapat menimbulkan kegelisahan

\section{METODE PENELITIAN}

Penelitian ini merupakan kajian pustaka. Metode yang digunakan dalam penelitian ini adalah melakukan analisis dengan data sekunder, yaitu kajian pustaka terhadap beberapa referensi yang mendukung seperti dasar teori implementasi penerapan CWS sebagai pengkajian psikologis dalam ANC Rutin. Beberapa referensi dikutip dan dikaji kemudian di buat analisisnya. Analisis dibuat dengan mengetahui langkah-langkah manajemen 
asuhan kebidanan dan dikaji satu persatu yang berkaitan dengan kemampuan yang harus dimiliki oleh seorang profesi bidan yaitu berpikir kritis sehingga menghasilkan suatu keputusan yang rasional dan tepat.

\section{HASIL DAN PEMBAHASAN}

Pendekatan psikososial kehamilan merupakan suatu pendekatan psikologi dan sosial terhadap wanita yang sedang berada dalam tahap kehamilan yang mengalami berbagai macam perubahan fisik maupun psikologis dimana perubahan-perubahan ini dapat dipengaruhi oleh interaksi wanita hamil dengan lingkungan sosial (masyarakat).

Kehamilan merupakan suatu momen yang didambakan oleh setiap pasangan sudah menikah, terutama perempuan. Sebagian besar dari mereka menyambutnya dengan suka cita, karena tidak lama lagi buah hati yang didambakan akan lahir dan hidup ke dunia yang akan menjadi generasi penerus mereka. Namun, terkadang kehamilan terasa berat dijalankan, karena berbagai kebebasan perempuan yang dimiliki kini terkurangi dan akan hilang untuk sementara waktu.

Perempuan hamil akan mengalami perubahan-perubahan psikologis baik perubahan positif maupun negatif. Perubahan positif seperti munculnya sifat keibuan dan pemahaman yang lebih baik tentang peran ibu terhadap anakanaknya. Perubahan negatif biasanya mengiringi ibu hamil, diantaranya muncul konsep diri negatif, seperti perempuan hamil merasa secara fisik tidak menarik lagi, sehingga memiliki kekhawatiran ditinggal suaminya. Untuk itu, perempuan hamil membutuhkan dukungan psikologis maupun psikososial dari orang-orang terdekat yang berada di lingkungannya.

Kondisi stress dan cemas hampir meliputi semua perempuan hamil, lebih-lebih pada kehamilan pertama dimana individu sama sekali kurang mengerti perubahan-perubahan yang baru terjadi. Secara umum dukungan psikososial dapat menurunkan tingkat stress dan bahkan dapat menjaga kesehatan mental yang bersangkutan. Berbagai macam tipe dukungan psikososial yang telah diidentifikasikan dan dikategorisasikan, misalnya dukungan harga diri, dukungan informasi, dukungan yang debrikan secara nyata, dan persahabatan sosial.

Selama kehamilan, dukungan psikososial, sangat membantu dalam menjaga atau mengontrol kondisi emosional, tiga fungsi dukungan psikososial yang disebut healthsustaining (Wita, 2011), sabagai berikut, pertama Gratification of affiliative needs, yaitu dukungan psikososial untuk menegaskan bahwa seseorang merupakan bagian dari kelompok dan diterima dalam norma-norma masyarakat.

Kedua, Self identity maintanance and enhancement, yaitu dukungan sosial berfungsi sebagai baromater untuk mengukur kualitas interaksi seseorang dengan orang lain. Ketiga, Self-esteem eanhancement, yaitu sebagai penegasan kembali atas nilai-nilai yang dimiliki oleh yang bersangkutan kepada orang lain bahwa dirinya adalah pribadi yang baik

Kehamilan dapat dianggap sebagai Krisis, artinya Kehamilan, terutama kehamilan yang pertama kali pada pasangan, mewakili suatu masa krisis dalam evolusi sebuah keluarga. Krisis merupakan ketidakseimbangan psikologis yang dapat disebabkan oleh situasi atau oleh tahap perkembangan yang terjadi pada seorang wanita hamil.

Kehamilan juga dapat dianggap sebagai stressor, yaitu model konseptual menyatakan bahwa krisis psikologis dan sosial dipertimbangkan, sebagai kejadian yang kritis tapi tidak selalu ditunjukkan dengan masalah psikologis dan interpersonal yang nyata. Setiap perubahan yang terjadi pada seseorang dapat merupakan stresor. Kehamilan membawa perubahan yang signifikan pada ibu sehingga dapat dinyatakan sebagai stresor, yang juga mempengaruhi psikologis anggota keluarga lainnya.

Kehamilan juga dapat dianggap sebagai transisi peran. Transisi peran terjadi perubahan interaksi rutin dalam keluarga, dengan adanya anggota keluarga yang baru sehingga terjadi perubahan peran masing-masing anggota keluarga: ayah, ibu, dan anggota keluarga yang lainnya.

Faktor psikologis yang berpengaruh dalam kehamilan dapat berasal dari dalam diri ibu hamil (internal) dan dapat juga berasal dari faktor luar diri ibu hamil (eksternal).). Faktor psikologis yang mempengaruhi kehamilan 
berasal dari dalam diri ibu dapat berupa latar belakang kepribadian ibu dan pengaruh perubahan hormonal yang terjadi selama kehamilan (Rukiya, 2009)

Emosi naik turun sering sekali terjadi pada ibu hamil. Banyak ibu hamil yang lebih mudah menangis tanpa sebab jelas. Terdapat tiga hormon yang naik secara signifikan ketika hamil, yaitu estrogen (hormon paling dominan yang diproduksi ovum); progesterone (hormon yang memiliki tanggung jawab menyeimbangkan hormon estrogen, diproduksi corpus luteum saat awal kehamilan dan di plasenta saat akhir kehamilan). Dan terakhir, gonadotropin yang lebih dikenal dengan hCG, yang diproduksi oleh plasenta. Berubahnya level hormon tersebut mengubah neurotransmitter, suatu saraf yang memberikan sinyal ke otak untuk mengatur mood ibu hamil.

Progesteron menyebabkan pembuluh darah melebar yang mengakibatkan tekanan darah rendah dan pusing. Ia juga dapat menyebabkan sistem pencernaan terganggu, menyebabkan rasa mual, mempengaruhi emosi dan meningkatkan suhu badan. Sedangkan estrogen mempengaruhi pembentukan protein neurokimia dan reseptor di sistem saraf pusat sehingga dapat menyebabkan terjadinya perubahan psikologis pada ibu hamil.

Perubahan trimester pertama (Periode Penyesuaian) merupakan periode ibu merasa tidak sehat dan kadang merasa benci dengan kehamilannya., periode ibu sering merasa minder dan mengurangi interaksi sosial dengan lingkungan.pada periode ini kadang muncul penolakan, kekecewaan, kecemasan, dan kesedihan. Bahkan kadaang ibu berharap agar dirinya tidak hamil saja. Selain itu, ibu akan selalu mencaari tanda-tanda apakah ia benarbenar hamil. Hal ini dilakukan sekedar untuk meyakinkan dirinya.

Pada periode pertama ini, seorang wanita hamil menginginkan bahwa setiap perubahan yang terjadi dalam dirinya akan selalu mendapat perhatian dengan seksama. Oleh karena perutnya, masih kecil, kehamilan merupakan rahasia seorang ibu yang mungkin akan diberitahukannya kepada orang lain atau malah mungkin dirahasiakannya, dan hasrat untuk melakukan hubungan seks berbeda-beda pada tiap wanita, tetapi kebanyakan akan mengalami penurunan.

Berbeda dengan perubahan trimester kedua yang terdiri dari dua fase, yaitu fase prequickening dan postquickening. Pertama fase prequickening, artinga selama akhir trimester pertama dan masa preqiuckening pada trimester kedua, ibu hamil mengevaluasi lagi hubungannya dan segala aspek di dalammya dengan ibunya yang telah terjadi selama ini. Ibu menganalisa dan mengevaluasi kembali segala hubungan interpersonal yang telah terjadi dan akan menjadi dasar bagaimana ia mengembangkan hubungan dengan anak yang akan dilahirkannya. Ia akan menerima segala nilai dengan rasa hormat yang telah diberikan ibunya, namun bila ia menemukan adanya sikap yang negatif, maka ia akan menolaknya. Perasaan menolak terhadap sikap negatif ibunya akan menyebabkan rasa bersalah pada dirinya. Kecuali bila ibu hamil menyadari bahwa hal tersebut normal karena ia sedang mengembangkan identitas keibuannya.

Proses yang terjadi dalam masa pengevaluasian kembali ini adalah perubahan identitas dari penerima kasih sayang (dari ibunya) menjadi pemberi kasih sayang (persiapan menjadi seorang ibu). Transisi ini memberikan pengertian yang jelas bagi ibu hamil untuk mempersiapkan dirinya sebagai ibu yang memberikan kasih sayang kepada anak yang akan dilahirkannya. Trimester kedua sering dikatakan periode pancaran kesehatan. Ini disebabkan selama trimester ini wanita umumnya merasa baik dan terbebas dari ketidaknyamanan kehamilan.

Kedua, fase postquickening, artinya setelah ibu hamil merasakan quickening, identitas keibuan yang jelas akan muncul. Ibu hamil akan fokus pada kehamilannya dan persiapan menghadapi peran baru sebagai seorang ibu. Perubahan ini bisa menyebabkan kesedihan meninggalkan peran lamanya sebelum kehamilan, terutama pada ibu yang mengalami hamil pertama kali dan wanita karir. Ibu harus diberikan pengertian bahwa ia tidak harus membuang segala peran yang ia terima sebelum kehamilannya.

Pada wanita multigravida, peran baru artinya bagaimana ia menjelaskan hubungan dengan anaknya yang lain dan bagaimana bila 
nanti ia harus meninggalkan rumahnya untuk sementara pada proses persalinan. Pergerakan bayi yang dirasakan membantu ibu membangun konsep bahwa bayinya adalah individu yang terpisah dari dirinya. Hal ini menyebabkan perubahan fokus pada bayinya. Pada saat ini, jenis kelamin bayi tidak begitu dipikirkan karena perhatian utama adalah kesejahteraan janin (kecuali beberapa suku yang menganut sistem patrilineal atau matrilineal).

Perubahan trimester ketiga dapat terjadi antara lain, gerakan bayi dan membesarnya perut merupakan dua hal yang mengingatkan ibu akan bayinya. Kadang - kadang ibu merasa khawatir bahwa bayinya akan lahir sewaktu - waktu. Ini menyebabkan ibu meningkatkan kewaspadaannya akan timbulnya tanda dan gejala akan terjadinya persalinan. Ibu seringkali merasa khawatir atau takut kalau - kalau bayi yang akan dilahirkannya tidak normal. Kebanyakan ibu juga akan bersikap melindungi bayinya dan akan menghindari orang atau benda apa saja yang dianggapnya membahayakan bayinya.

Kehamilan bagi keluarga dan khususnya seorang wanita merupakan peristiwa yang penting, meskipun demikian kehamilan juga merupakan saat-saat krisis bagi keluarga di mana terjadi perubahan identitas dan peran ibu, ayah, serta anggota keluarga lainnya. Tugas ibu pada masa kehamilan :

1. Menerima kehamilannya

2. Membina hubungan dengan janin

3. Menyesuaikan perubahan fisik

4. Menyesuaikan perubahan hubungan suami istri

5. Persiapan melahirkan dan menjadi orang tua

Seorang ibu mulai merasa takut akan rasa sakit dan bahaya fisik yang akan timbul pada waktu melahirkan. Rasa tidak nyaman akibat kehamilan timbul kembali pada trimester ketiga dan banyak ibu yang merasa dirinya aneh dan jelek. Disamping itu ibu mulai merasa sedih karena akan berpisah dari bayinya dan kehilangan perhatian khusus yang diterima selama hamil. Pada trimester inilah ibu memerlukan keterangan dan dukungan dari suami, keluarga dan bidan.

Trimester ketiga sering kali disebut periode menunggu / penantian dan waspada sebab pada saat itu ibu merasa tidak sabar menunggu kelahiran bayinya. Trimester III adalah waktu untuk mempersiapkan kelahiran dan kedudukan sebagai orang tua seperti terpusatnya perhatian pada kehadiran bayi. Trimester ketiga merupakan saat persiapan aktif untuk kelahiran bayi yang akan dilahirkan dan bagaimana rupanya. Mungkin juga nama bayi yang akan dilahirkan juga sudah dipilih. Trimester ketiga adalah saat persiapan aktif untuk kelahiran bayi dan menjadi orang tua. Keluarga mulai menduga - duga tentang jenis kelamin bayinya ( apakah laki- laki atau perempuan ) dan akan mirip siapa.

Wanita dengan kecemasan terkait kehamilan mungkin mengalami gejala seperti nyeri otot, Palpitasi, kelelahan, sakit kepala, sakit perut, gangguan tidur, mimpi buruk, dan insomnia Yang dapat mempengaruhi kesehatan ibu dan kualitas hidup. Kecemasan ibu telah menjadi risiko Faktor untuk hasil perinatal yang buruk seperti kelahiran prematur, depresi pascamelahirkan, operasi caesar, Dan hasil perkembangan anak yang buruk. Dengan demikian, penting untuk mengukur sejauh mana dan Isi kegelisahan dan kekhawatiran selama masa kehamilan.

Inventori Kecemasan Negara-Trait (STAI) telah menjadi instrumen yang banyak digunakan di wilayah Indonesia Kecemasan dan kecemasan terkait kehamilan. Ada masalah dengan menggunakan STAI sebagai ukuran Kecemasan dan kecemasan terkait kehamilan. Yang pertama adalah bahwa STAI hanya bisa mengukur tingkat keparahannya Kecemasan dan tidak bisa mengungkapkan alasan kecemasan. Masalah kedua adalah bahwa STAI Mengukur kecemasan umum sementara kemungkinan bahwa seorang ibu yang tidak biasanya depresi Atau saat ini cemas untuk alasan lain khawatir tentang kesehatan bayi atau persalinannya. Hasil sebuah penelitian menemukan bahwa kecemasan dan depresi umum menjelaskan 8-27\% variasi Dalam kekhawatiran terkait kesehatan janin dan persalinan pada trimester pertama dan kedua Kehamilan.

Apalagi, meski kekhawatiran dan kecemasan saling terkait satu sama lain, ada perbedaan Antara dua konsep tersebut. Kecemasan terdiri dari kognitif, somatik, emosional, dan Elemen perilaku, sedangkan khawatir ditentukan sebagai komponen kognitif 
kecemasan dengan efek positif yang signifikan terhadapnya. Dimensi kognitif kecemasan terkait kehamilan meliputi Kesehatan janin, kehilangan janin, persalinan, kesehatan ibu, citra tubuh, pengasuhan dan perawatan Dukungan anak, kesehatan, keuangan, keluarga dan sosial. Jadi, spesifik. Instrumen dibutuhkan untuk mengukur kekhawatiran pada wanita hamil.

Kesehatan mental selama kehamilan merupakan hal yang penting dalam perawatan antenatal. Masalah ini berkisar Dari depresi (baik kecil maupun besar), gangguan kecemasan, skizofrenia, dan psikosis. Kehidupan Menekankan sebagai duka cita, perpisahan, pengangguran, penyakit, migrasi pindah rumah, kekurangan Dukungan sosial, sejarah kelainan psikologis atau psikiatri masa lalu, sejarah fisik, Pelecehan emosional atau seksual, penyalahgunaan obat-obatan atau alkohol, gaya koping, dan perilaku mengasuh anak dapat dilakukan Berkontribusi onset Perasaan dan mood wanita saat hamil bisa berdampak pada Perkembangan bayi baik selama kehamilan maupun setelah kelahiran. Menilai perempuan untuk Faktor risiko psikologis dan gejala selama kehamilan memberi kesempatan untuk terhubung Wanita dengan layanan yang tepat.

Penggunaan asesmen psikologis antenatal dapat meningkatkan kesadaran bidan Risiko psikososial dan juga meningkatkan hasil kesehatan mental perinatal. Biasa psikologis Penilaian yang digunakan di Indonesia untuk mendapatkan perasaan dan status emosional wanita juga Sederhana dan tidak cukup untuk menggambarkan perasaan wanita. Banyak kuesioner telah Dikembangkan dan diuji di banyak negara namun tidak satupun yang telah diuji di Indonesia.

Salah satu penilaian psikologis antenatal adalah skala kekhawatiran Cambridge. Berdasarkan hal tersebut Latar belakang saya memiliki minat untuk belajar tentang "Implementasi skala kekhawatiran Cambridge sebagai Penilaian psikologis dalam rutinitas perawatan antenatal ". Proyek ini akan meningkatkan bidan Kesadaran dalam menggunakan asesmen psikologis antenatal dalam pelayanan antenatal rutin, sehingga Faktor risiko psikologis dan psikososial selama kehamilan akan dinilai dengan cepat dan Wanita dengan faktor risiko psikososial akan memiliki perawatan yang sesuai.

Deteksi psikologis Faktor risiko, kita dapat mencegah hasil kelahiran yang buruk dan perkembangan bayi dan anak yang buruk. Dengan menggunakan skala kekhawatiran Cambridge dalam penilaian antenatal, faktor risiko psikologis Deteksi akan tepat dan cukup baik untuk menggambarkan status emosional dan psikologis Perempuan. Karena pengakuan kekhawatiran yang tak terkendali berlebihan sebagai fitur utama yang umum Gangguan kecemasan dalam DSM-IV, langkah-langkah khawatir telah dikembangkan dengan fokus pada Intensitas kekhawatiran dan area kekhawatiran.

Untuk alasan tersebut, Statham dkk. Mengembangkan Cambridge Worry Scale (CWS) untuk menyelidiki prevalensi dan kandungan kekhawatiran selama Kehamilan. CWS 17-theem termasuk item yang menilai kekhawatiran terkait kehamilan. Dan kekhawatiran kehidupan sehari-hari. Mereka memeriksa CWS di "Cambridge Prenatal Screening Studi, "sebuah penelitian longitudinal terhadap 1072 wanita hamil di mana kekhawatiran perempuan terjadi Dinilai dalam usia kehamilan 16-, 22, dan 35 minggu.

Dalam sebuah studi validasi, mereka memeriksa CWS 1207 wanita hamil Struktur empat faktor dari kekhawatiran wanita hamil ditemukan (Sosiomedis, kesehatan sendiri, sosioekonomi, dan relasional). Skala menunjukkan bagus Reliabilitas dan validitas dan subskala CWS berkorelasi dengan kecemasan keadaan dan sifat. Ada 3 alasan mengapa proyek ini inovatif :

1. Tidak ada penelitian tentang penerapan skala kekhawatiran Cambridge sebagai antenatal Penilaian psikologis di indonesia

2. Penilaian psikologis antenatal di Indonesia benar-benar sederhana dan status psikologis Hanya didapat satu pertanyaan "Apa yang anda rasakan tentang kehamilan anda".

3. Banyak wanita hamil tidak puas hanya dengan satu pertanyaan tentang status psikologis mereka.

Wanita yang sedang hamil, pasti akan mengalami berbagai macam perubahan bukan hanya perubahan secara fisik namun juga secara psikologis dan sosial. Jangan heran jika ibu yang hamil tiba-tiba menangis atau marah. Ini terjadi 
karena adanya perubahan hormonal yang lazim dialami oleh ibu-ibu yang sedang hamil. Untuk itu ibu-ibu yang kini sedang mengandung buah hati, harus selalu menjaga kondisi psikologisnya agar tetap baik dan seimbang. Jika kondisi psikologis sang ibu baik pastinya sang ibu akan lebih tenang atau rileks saat menjalani masamasa kehamilannya.

Berikut beberapa cara yang dapat menyeimbangkan kondisi psikologis dan sosial wanita hamil :

1. Informasi

Cari informasi seputar kehamilan terutama mengenai perubahan yang terjadi dalam diri ibu termasuk hal-hal yang perlu dihindari saat sedang mengandung agar janin tumbuh sehat. Pengetahuan atau informasi yang tepat akan membuat ibu merasa lebih yakin sekaligus bisa mengurangi rasa cemas yang sering muncul karena ketidaktahuan mengenai perubahan yang terjadi.

2. Komunikasi dengan suami

Bicarakan perubahan yang terjadi selama hamil dengan suami, sehingga ia juga tahu dan dapat memaklumi perubahan yang terjadi. Apabila sudah dikomunikasikan, sang suami akan memberikan dukungan psikologis yang dibutuhkan.

3. Rajin memeriksakan kehamilan

Periksakan kehamilan secara teratur. Cari informasi dari dokter atau bidan terpercaya mengenai kehamilan. Jangan lupa, ajaklah suami saat berkonsultasi ke dokter atau bidan.

4. Mengkonsumsi makanan yang bergizi

Pahami benar pengetahuan mengenai asupan makanan yang sehat bagi perkembangan janin. Hindarilah mengonsumsi bahan yang dapat membahayakan janin, seperti makanan yang mengandung zat-zat aditif, alkohol, rokok, atau obat-obatan yang tidak dianjurkan bagi ibu hamil. Jauhkan juga zat berbahaya seperti gas buang kendaraan yang mengandung timah hitam yang berbahaya bagi perkembangan kecerdasan otak janin.

5. Jaga Penampilan

Perhatikanlah penampilan fisik dengan menjaga kebersihan dan berpakaian yang sesuai dengan kondisi badan yang sedang berbadan dua. Jangan lupa untuk melakukan latihan fisik ringan, seperti berenang atau jalan kaki ringan untuk memperlancar sirkulasi darah dan membuat ibu menjadi lebih rileks sehingga keadaan emosinal dapat terjaga.

6. Mendengarkan musik Upayakan berbagai cara agar terhindar dari stres. Atasilah kecemasan maupun emosi negatif lainnya dengan mendengarkan musik lembut, belajar memusatkan perhatian, berzikir, yoga atau relaksasi lainnya.

7. Senam hamil

Bergabunglah dengan kelompok senam hamil sejak usia kandungan menginjak usia 5-6 bulan. Jangan lupa untuk berkonsultasi terlebih dahulu dengan dokter kandungan. Senam hamil tidak hanya bermanfaat melatih otot-otot yang diperlukan dalam proses persalinan, melainkan juga memberi manfaat psikologis dan sosial, dimana ibu dapat berinteraksi dengan ibu-ibu hamil lainnya. Pertemuan sesama calon ibu biasanya diisi dengan acara berbagi pengalaman yang dapat dijadikan pelajaran positif. Melalui kegiatan itu pula secara perlahan kesiapan psikologis calon ibu dalam menghadapi persalinan menjadi semakin mantap.

Disamping itu, menurut Anthoni, (1998) pedekatan atau konseling bidan terkait permasalahan perubahan psikososial ibu hamil adalah :

1. Jalin komunikasi yang baik dengan ibu sehingga ibu merasa diperhatikan dan terbuka dalam mengkomunikasikan permasalahan yang sedang dialaminya.

2. Memberitahu tahu ibu tentang perubahanperubahan psikologis yang mungkin terjadi selama kehamilan

3. Memberitahu ibu dampak masalah psikologis yang dihadapi oleh ibu terhadap janin yang dikandungnya

4. Rencana jangka panjang menganjurkan ibu untuk menggunakan kontrasepsi, jika terkait masalah ekonomi beritahu ibu beberapa alternative metode kontrasepsi yang dapat digunakan oleh ibu.

5. Menganjurkan ibu untuk mencari pihak ketiga sebagai penengah seperti keluarga atau orang tua sehingga diharapkan permasalahan dapat terselesaikan dengan baik secara kekeluargaan 
6. Menganjurkan ibu untuk komunikasikan permasalahan yang dialami dalam rumah tangga nya dengan suami secara baik dan terbuka, diharapkan suami dapat memahami dan memberikan dukungan psikologis terhadap kehamilan ibu. .

7. Anjurkan ibu untuk mengikutsertakan suami ketika melakukan kunjungan antenatal sehingga bidan lebih mudah dalam menyampaikan konseling .

8. Memberikan pendampingan psikologis dan pelayanan pengobatan fisik korban jika diketahui ibu mengalami kekerasan fisik

9. Jika terjadi permasalahan yang lebih berat pada ibu sampai menyebabkan depresi berat pada ibu segera fasilitasi ibu untuk berkonsultasi dengan psikiater, karena sudah tidak menjadi wewenang seorang bidan lagi.

Dengan melihat rentang hidup total dalam hal interaksi tugas perkembangan, rentang hidup manusia dapat dilihat sebagai suatu siklus yang terdiri dari beberapa tahap atau fase, yang masing-masing memiliki tugas unik. Ketika berbagai siklus terjadi, peran sosial terbentuk dari interaksi dengan orang lain dalam jaringan sosial.

Analoginya, peran sosial bisa dikatakan memiliki siklus, dan tiap tahap dalam siklus memiliki serangkaian tugas dan penyesuaian diri. Para peneliti keluarga telah menguraikan empat tahapan besar dalam siklus peran yang berdampak pada kehamilan dan menjadi orang tua

Tahap Awal (antisipasi). Dalam tahap ini wanita akan mengawali adaptasi perannya dengan merubah peran sosialnya melalui latihan formal (misalnya kelas-kelas khusus kehamilan) dan informal melalui model peran (role model). Meningkatnya frekuensi interaksi dengan wanita hamil dan ibu muda lainnya akan mempercepat proses adaptasi untuk mencapai penerimaan peran barunya sebagai seorang ibu.

Tahap Honeymoon (menerima peran, mencoba menyesuaikan diri). Pada tahap ini wanita sudah mulai menerima peran barunya dengan cara mencoba menyesuaikan diri. Secara internal wanita akan mengubah posisinya sebagai penerima kasih sayang dari ibunya menjadi pemberi kasih sayang terhadap bayinya. Untuk memenuhi kebutuhan akan kasih sayang, wanita akan menuntut dari pasangannya. Ia akan mencoba menggambarkan figur ibunya dimasa kecilnya dan membuat suatu daftar hal-hal yang positif dari ibunya untuk kemudian ia daptasi dan terapkan kepada bayinya nanti. Aspek lain yang berpengaruh dalam tahap ini adalah seiring dengan sudah mapannya beberapa persiapan yang berhubungan dengan kelahiran bayi, termasuk dukungan semangat dari orang-orang terdekatnya.

Tahap Plateu (periode pertengahan). Tahap sebelumnya mengalami peningkatan sampai ia mengalami suatu titik stabil dalam penerimaan peran barunya. Ia akan melakukan aktivitas-aktivitas yang bersifat positif dan berfokus untuk kehamilannya, seperti mencari tahu tentang informasi seputar persiapan kelahiran, cara mendidik dan merawat anak, serta hal yang berguna untuk menjaga kondisi kesehatan keluarga.

Tahap Pelepasan (perjanjian). Meskipun ia sudah cukup stabil dalam menerima perannya, namun ia tetap mengadakan "perjanjian" dengan dirinya sendiri untuk sedapat mungkin "menepati janji" mengenai kesepakatankesepakatan internal yang telah ia buat berkaitan dengan apa yang akan ia perankan sejak saat ini sampai bayinya lahir kelak.

\section{KESIMPULAN}

Penerapan skala kekhawatiran Cambridge dalam antenatal Penilaian psikologis bisa dijadikan Penilaian rutin antenatal psikologis di setiap perawatan antenatal. Identifikasi status psikologis ibu hamil dapat berkontribusi secara signifikan Kecemasan dan kekhawatiran pengurangan jika konseling antenatal yang adekuat, saran dan perawatan yang sesuai Mungkin diberikan untuk ibu hamil tertentu ini. Selain itu, studi masa depan di Hubungan antara kekhawatiran pada kehamilan dan faktor prediksi diperlukan. Fakta bahwa Sikap terhadap penilaian risiko, dan hal-hal terkait tambahan dikaitkan dengan yang pasti Faktor demografis demografi mungkin juga sangat relevan untuk praktik klinis.

Pendekatan psikososial kehamilan merupakan suatu pendekatan psikologi dan sosial terhadap wanita yang sedang berada dalam tahap kehamilan yang mengalami 
berbagai macam perubahan fisik maupun psikologis.

Sumber-sumber dukungan psikososial yaitu suami, anggota keluarga lain serta lingkungan. Kehamilan dapat dianggap sebagai masa krisis, stressor dan transisi peran dimana pada akhirnya ibu akan menikmati peran barunya sebagai seorang calon ibu.

Bidan berperan dengan focus meningkatkan harga diri ibu, memfasilitasi ekspresi perasaan ibu, dan meningkatkan lingkungan social yang memungkinkan. Bidan berperan penting dalam upaya membantu korban kekerasan diantaranya melalui upaya pencegahan primer terdiri dari konseling keluarga, modifikasi lingkungan social budaya dan pembinaan spiritual, upaya pencegahan sekunder berupa asuhan-asuhan, pencegahan tertier melalui pelatihan atau pendidikan. Memberikan pendampingan hukum dalam acara peradilan.

\section{UCAPAN TERIMA KASIH}

Ucapan terima kasih diberikan kepada Program Studi S1 Kebidanan Fakultas Kedokteran Universitas Andalas yang selalu memberikan dukungan dan dorongan di setiap kegiatan penelitian yang dilakukan.

\section{DAFTAR PUSTAKA}

Ahmadi, Abu. 2002. Psikologi Sosial. Jakarta: Rineka Cipta

Anthoni J. Reid, A.B. 1998. Using The ALPHA Form In Practicwe To Asses Antenatal Psychosocial Health. Canadian Medical Association

Brown JM, Alverson EM, Pepa CA. 2001. The influence of a baccalaureate program on traditional, RN-BSN, and accelerated students' critical thinking abilities. Holist Nurs Pract 15(3).pp. 4-8. Available at http://www.ncbi.nlm.nih.gov/pubmed/12120 110

Fenech, Giliane, 2016. Critical reflection in midwifery practice: the protection motivation theory. Journal Reflective Practice, 17(3). Available at http://dx.doi.org/10.1080/14623943.2016.116 4680

Fisher, Alec. 2001. Critical Thinking An Introduction. United Kingdom; Cambridge University Press. Pp.1-14

ICM. 2014. The International Confederation of Midwives Dissemination Pack. Global Standard, Competencies and Tools. Available at http://www.internationalmidwives.org/assets/ uploads/documents/Dissemination/140508\% 20Dissemination\%20ICM\%20V06.pdf

Jefford, E., Kathleen Fahy \& Deborah Sundin. 2011. Decision-making Theories and their usefulness to the midwifery profession both in terms of midwifery practice and the education of midwifes. International Journal of Nursing Practice, 17 (3), pp. 246-253

Kuhn, D., \& Dean, D. 2004. A bridge between cognitive psychology and educational practice. Theory into Practice, 43(4).pp. 268-273. Available at https://www.researchgate.net/publication/232 869320_Metacognition_A_Bridge_Between Cognitive_Psychology_and_Educational_Pra ctice

Reeder, dkk. 2011. Keperawatan Maternitas Kesehatan Wanita, Bayi dan Keluarga Volume 1. Jakarta: EGC

Unknown, 2009. Ilmu Psikologi. Diperoleh tanggal 20 September 2013 melalui http://ilmupsikologi.blogspot.com/2009/05/psikologisosial.html

Unknown, 2011. Perubahan dan Adaptasi Psikologi Masa Kehamilan. Diperoleh melalui http://www.lusa.web.id/perubahandan-adaptasi-psikologis-dalam-masakehamilan/

Walsh, Linda V. 2007. Kebidanan Komunitas. Jakarta: EGC

Wita. 2011. Dukungan Psikososial Kehamilan. Diperoleh tanggal 20 September 2013 melalui htt://witablogger.blogspot.com/2011/05/Duk ungan-psikososial-Kehamilan

Lai, Emily.R. 2011. Critical Thinking : a Literature Review Research Report. Pearson. Available at http://images.pearsonassessments.com/image s/tmrs/CriticalThinkingReviewFINAL.pdf 
Mottola CA, Murphy P. 2001. Antidote dilemma - an activity to promote critical thinking. Journal of Continuing Education in Nursing 32(4).pp.161-164.

Paul, Richard and Linda Elder. 2006. Critical Thinking "Concepts and Tools. The Foundation for Critical Thinking. Available at

https://www.criticalthinking.org/files/Concep ts Tools.pdf

Schraw, G., Crippen, K. J., \& Hartley, K. 2006. Promoting self-regulation in science education: Metacognition as part of a broader perspective on learning. Research in Science Education, 36 (1).pp. 111-139. Available at http://link.springer.com/article/10.1007/s111 $\underline{65-005-3917-8}$
Schin S, Ha J, Shin K, et al. 2006. Critical thinking ability of associate, baccalaureate and RN-BSN senior students in Korea. Nurs Outlook 54(6).pp.328-333. Available at http://www.nursingoutlook.org/article/S0029 -6554(06)00253-3/abstract

The Open University. 2008. Thinking Critically. United Kingdom : Thanet Press. Available at https://www.openpolytechnic.ac.nz/assets/Le arning-Central/Critical-thinking-OpenUniversity.pdf

Varney Helen., Jan.M Krie \& Carolyn L.Gegor. 2004. Varney's Midwifery. Journal of Midwifery \& Women's Health 49(1), pp 6263 available at http://www.sciencedirect.com/science/article/ pii/S1526952303004203 